Shamyla Chaudry 129

Note:

\title{
How Does Environmental Economics Function?
}

\section{Shamyla Chaudry}

In economics we study how and why "people" whether they are consumers, firms, non-profit organisations or government agencies make decisions about the use of valuable limited resources. When studying the environment from an economics perspective we are in fact primarily focusing on how and why "people" make decisions that have environmental consequences. Secondly, we focus on how we can manage institutions to bring these environmental impacts more into balance with changing human demands and the demands of the ecosystem itself.

If we follow this economic approach several answers emerge to the basic question asked in environmental economics, that is "Why do people behave in ways that cause environmental degradation?"

Some believe that environmental degradation is a result of human behaviour that is unethical or immoral. Therefore, people pollute the environment because they lack the moral and ethical strength to refrain from behaviour that leads to environmental destruction. But this approach is too general as it is not moral underdevelopment that leads to environmental destruction, rather, it is the way economic systems within which people earn a living are ordered. This is simply saying that people pollute for it is the "cheapest" way to solve a practical problem.

People make decisions on production, consumption and disposal within a certain set of economic and social institutions. These institutions structure incentives that lead people to make decisions in one direction and not in the other. An "incentive-type" statement would say "pollution is a result of the profit motive" but this would only apply for a private firm. Examples for this can clearly be seen by certain studies done at the Lahore School of Economics. Firstly, Kasur the leather tanneries environmental analysis clearly outlines this phenomena where the individuals are not willing to spend to clear the waste that is produced simply because there is no check and they can easily get away with it ${ }^{1}$. These firms are not willing to spend their human resources simply because of the "cost" that is attached to health insurance. Another showed how hospitals were reacting to the high rates of pollution in Lahore. Private hospitals such as Hameed Latif are spending on a clean and hygienic environment within the hospitals but they

${ }^{1}$ Lahore School of Economics, Case Study, 1997. "Environmental Analysis of Kasur Leather Tanneries". 
dump their wastes outside in the MCL containers and are not willing to pay the additional cost of an incinerator ${ }^{2}$. These are all examples of pollution caused by private entities.

We know for a fact that individuals and public or government agencies are not profit oriented still some have been serious polluters, e.g., the USSR and Eastern Europe ${ }^{3}$. Studies done in Lahore's Katchi Abadis proves the point that pollution is not necessarily a result of the clear profit motive but in fact environmental problems are problems of poverty ${ }^{4}$.

A more convincing and permissive argument against the view is that "search for profit" causes pollution. The profit motive, in itself, is not the main cause of environmental destruction. Therefore any system will produce destructive environmental impacts if the incentives within that system are not structured to avoid them.

So in seeing the economic approach we have in fact deduced that environmental degradation is mainly caused by how people act or react within a given system. Therefore, we see that Environmental Economics draws from two sides - firstly, the study of water management flows and secondly, the impact of human activity on environmental resources.

Inferring from the last statement, how can we ensure environmental quality in a country? The friture is not independent of the choices we make today, that is, if we degrade the environment today our future generations are likely to suffer more. Therefore, to clearly understand this we have to see the short run and long run choices available to us.

Using Production Possibilities Curve for our analysis we can explain the choices available to us.

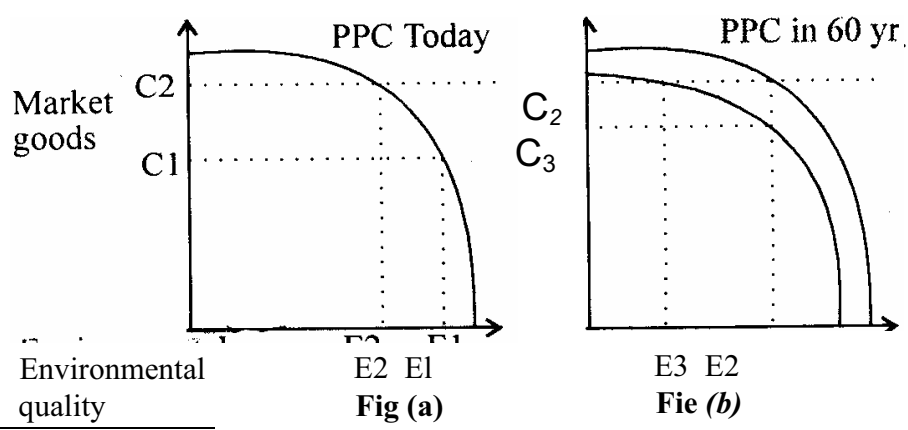

\footnotetext{
${ }^{2}$ Lahore School of Economics, Case Study, 1997. Hospitals Polluting or Being Polluted.

${ }^{3}$ Field, Barry E. Environmental Economics: An Introduction.

4 Lahore School of Economics, Case Study, 1997. "Environmental Problems in the Katchi Abadis".
} 
In figure (a) we have PPC today showing that if the production of marketed goods increases from $\mathrm{C}_{1}$ to $\mathrm{C}_{2}$ then this happens at a cost, being a decrease in environmental quality from $e_{1}$ to $e_{2}$ In figure (a) we have PPC in 60 years. This shows that the future finds itself on the inner PPC where we have the same output $\mathrm{C}_{2}$, as we had in the previous analysis but now it will be a lower level of environmental quality, $\mathrm{e}_{3}$. OR we have a choice to have the same level of environmental quality as in our previous analysis, at $\mathrm{e}_{2}$ but we have lesser output at $\mathrm{C}_{3}$.

Therefore, we can conclude that if we limit production today we can have a better tomorrow in terms of environmental quality OR if we limit profits today we can have a more profitable future. 
132 The Lahore Journal of Economics, Vol.2, No.2

\section{References}

Field, Barry C., 1994. Environmental Economics: An Introduction. McGraw Hill International Edition, New York.

Goodstein, Eban, 1995. Economics and the Environment. Prentice Hall, New Jersey.

Lahore School of Economics, 1997. "Environmental Problems in Katchi Abadis Case Study".

Lahore School of Economics, 1997, "Hospitals Being Polluting or Being Polluted - Case Study".

Lahore School of Economics, 1997. "Environmental Analysis of Kasur Leather Tanneries - Case Study". 